\section{One new and three known species of Paratylenchus (Nematoda: Tylenchulidae) from Manipur, India}

\author{
M. Pramodini ${ }^{1} \&$ N. Mohilal ${ }^{2}$ \\ 1,2 Parasitology section, Department of Life Sciences, Manipur \\ University, Canchipur, Manipur 795003, India \\ Email: ${ }^{1}$ cd_paralab@ indiatimes.com, ${ }^{2}$ mohilaln@yahoo.co.in \\ (corresponding author)
}

Species of Paratylenchus Micoletzky, 1922 commonly known as "pin nematodes" are well-known plant pathogens of various agricultural crops. During a study of the plant parasitic nematodes associated with plant communities in Manipur, three known and one new species of Paratylenchus were recovered.

The nematodes were killed in hot water, fixed in $4 \%$ formaldehyde solution, dehydrated in Glycerine-Alcohol and were mounted in glycerine (Seinhorst 1959, 1962). Measurements were taken using an ocular micrometer.

Paratylenchus canchicus Mohilal \& Dhanachand 2004

Dimensions: Refer Table 1.

\section{Description}

Female: Body an open "C" after fixation. Head not set off, bluntly rounded, almost hemispherical, cephalic framework weakly developed. Stylet well-developed, stylet knobs posteriorly directed. Orifice of dorsal oesophageal gland located at $4.5 \pm 0.3(4-5) \mu \mathrm{m}$ from stylet base. Excretory pore distinct. Nerve ring located at 65.5 \pm 3.5 (60.8-70.4) $\mu \mathrm{m}$ from the anterior end. Oesophago-intestinal valve prominent. Ovary outstretched, spermatheca prominent. Tail narrows gradually to a rounded terminus. Lateral field with four incisures, equally distinct. Body annules $1.4 \pm 0.2(1.4-1.6) \mu \mathrm{m}$ wide. Vulva-anus distance $36.5 \pm 0.5(36.0-37.6) \mu \mathrm{m}$ or more than one tail length long.

Male: Not found.

Date of publication 26 March 2009

ISSN $0974-7907$ (online) | 0974-7893 (print)

Editor: Anwar L. Bilgrami

Manuscript details:

Ms \# 01744

Received 26 March 2007

Final received 16 August 2008

Finally accepted 16 December 2008

Citation: Pramodini, M. \& N. Mohilal (2009). One new and three known species of Paratylenchus (Nematoda: Tylenchulidae) from Manipur, India. Journal of Threatened Taxa 1(3): 177-179.

Copyright: (C) M. Pramodini \& N. Mohilal 2009. Creative Commons Attribution 3.0 Unported License. JoTT allows unrestricted use of this article in any medium for non-profit purposes, reproduction and distribution by providing adequate credit to the authors and the source of publication.

Acknowledgements: The authors express sincere thanks to the Head of Department of Life Sciences, Manipur University for providing laboratory facilities.

OPEN ACGESS | FREE DOWNLOAD
Habitat and locality

Soil around the roots of Alocasia indica Roxb. from Kakwa, Imphal West district.

\section{Remarks}

The morphological characters and dimension of the present specimens are in agreement with those original descriptions and dimensions provided by Mohilal \& Dhanachand (2004).

\section{Paratylenchus lepidus Raski 1975}

\section{Dimensions: Refer Table 1}

\section{Description}

Female: Body arcuate ventrally to an open 'C' after fixation, slightly more curved ventrad posterior to vulva. Body cuticle marked by fine transverse striae, about $1.0 \mu \mathrm{m}$ wide. Head rounded, without distinct annules. Stylet knobs squared-off or slightly posteriorly directed. Dorsal oesophageal gland orifice opens into lumen of oesophagus, about $7 \pm 0.8$ (6-8) $\mu \mathrm{m}$ behind the basal knobs. Oesophagus composed of distinct amalgamated procorpus and corpus with posteriorly located valve plates, narrow isthmus and rather rounded basal bulb. Cardia small, round. Nerve ring surrounds isthmus.

Ovary mono-prodelphic and outstretched. Spermatheca ovoid, prominent, with small spermatozoa. Vulva flaps distinct, large and rounded. Tail tapers gradually to a finely rounded terminus. Lateral field with four incisures, inner two slightly less distinct than outer two.

Male: Not found.

Habitat and locality:

Soil around the roots of Crotalaria juncea Linn. from Wakha, Imphal East district, Manipur.

\section{Remarks}

The dimensions and descriptions of the present specimens agree well with those provided by Raski (1975).

\section{Paratylenchus longicaudatus Raski 1975}

Dimensions: Refer Table 1

\section{Description:}

Female: Body curved ventrally upon fixation more towards posterior region of vulva. Cuticle with fine transverse annulations. Body gradually narrows at anterior end to head which is conoid and truncate. Lip region rounded with indistinct annules. Lateral fields with four incisures. Stylet slender with slightly posteriorly directed knobs. Orifice of dorsal oesophageal gland located at $5.4 \pm 0.4(5-6) \mu \mathrm{m}$ from stylet base. Median oesophageal bulb located at $63-88 \%$ of total

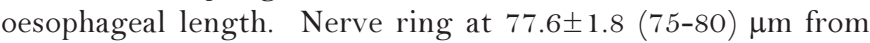
anterior end of body encircling the isthmus region. Cardia round, distinct.

Reproductive system mono-prodelphic and outstretched. Spermatheca oval shaped, with small spermatozoa. Vulval flaps large and rounded. Tail tapering to a finely rounded terminus.

Male: Not found 
Table 1. Measurements of three females of Paratylenchus spp. All measurements in $\mu \mathrm{m}$, except $\mathrm{L}$ in $\mathrm{mm}$.

\begin{tabular}{llll}
\hline Characters & $\begin{array}{l}\text { Paratylenchus canchicus } \\
\text { Mohilal \& Dhanachand, 2004 }\end{array}$ & $\begin{array}{l}\text { Paratylenchus longicaudatus } \\
\text { Raski, 1975 }\end{array}$ & $\begin{array}{l}\text { Paratylenchus lepidus } \\
\text { Raski, 1975 }\end{array}$ \\
\hline $\mathrm{n}$ & 12 & 10 & 15 \\
Length & $0.33-0.42(0.38 \pm 0.0)$ & $0.34-0.38(0.36 \pm 0.0)$ & $0.36-0.38(0.37 \pm 0.8)$ \\
$\mathrm{a}$ & $24.0-26.4(24.8 \pm 0.9)$ & $22-26(24 \pm 1.7)$ & $25-30(27.3 \pm 2.0)$ \\
$\mathrm{b}$ & $4.1-4.6(4.3 \pm 0.2)$ & $4.0-4.3(4.1 \pm 0.12)$ & $4.1-4.4(4.2 \pm 0.1)$ \\
$\mathrm{C}$ & $11.5-14.6(13 \pm 1.1)$ & $14-18(16 \pm 1.7)$ & $81-12(11.6 \pm 0.4)$ \\
$\mathrm{V}$ & $81.5-83.5(82 \pm 0.9)$ & $82-83(82.6 \pm 0.4)$ & $6-6.1(6.0 \pm 0.8)$ \\
Stylet \% L & $4.9-5.2(5 \pm 0.1)$ & $5.8-6.2(5.9 \pm 0.2)$ & $22.6-23.6(23.2 \pm 0.4)$ \\
Oesophagous. \% L & $21.7-24.3(23.2 \pm 0.9)$ & $23.2-25(23.8 \pm 0.6)$ & $22-24(23 \pm 0.8)$ \\
Stylet & $18.4-20.8(19.4 \pm 0.8)$ & $20-24(22 \pm 1.7)$ & $14-16(15 \pm 0.8)$ \\
Prorhabdion & $10.4-12(11.4 \pm 0.6)$ & $10-14(12 \pm 1.7)$ & $83-91(87.6 \pm 3.3)$ \\
Oesophagus & $87-91.7(89.5 \pm 1.7)$ & $83.9-90.2(87.2 \pm 2.4)$ & $6-8(7 \pm 0.8)$ \\
DGO & $4-5(4.5 \pm 0.3)$ & $5-6(5.4 \pm 0.4)$ & $12.9-14.6(13.8 \pm 0.6)$ \\
Body width & $15.2-15.9(15.4 \pm 0.2)$ & $14.9-15.6(15.2 \pm 0.3)$ & - \\
Tail & $28.8-32(30 \pm 1.3)$ & $25-27(26 \pm 0.8)$ & $76-80(71 \pm 0.8)$ \\
ABD & $8-9.6(9 \pm 0.6)$ & $8-10(9 \pm 0.8)$ & $61-64(62.3 \pm 1.6)$ \\
Excretory pore & $80.8-86.1(85.3 \pm 3.1)$ & $57-68(60.2 \pm 4.2)$ & \\
G & $36-40(38.2 \pm 1.4)$ & $29-31(30 \pm 0.8)$ & \\
\hline
\end{tabular}

\section{Habitat and localities}

Soil round roots of Cynodon dactylon $(\mathrm{L})$ Urban from Lamka, Churachandpur District.

Other recorded habitats and localities of Manipur:

Soil around roots of 1. Allium hookeri Thw. from Tronglaobi, Bishnupur District; 2. Banana, Musa sp. from Elangbam Leikei, Imphal District, Manipur.

\section{Remarks}

The dimensions and morphological characters of the present populations correspond well with type specimen described by Raski (1975).

\section{Paratylenchus thysanolus sp. nov. (Fig. 1)}

\section{Material examined}

Holotype: 28 May 2004, on slide no. PD 295, Parasitology Laboratory, Life Sciences Department, Manipur University, Canchipur, Imphal.

Paratype: Same information as above. on slides PD 288 (1-3), PD 295(1-4)

Dimensions: Tables $2 \& 3$

Etymology: The species is named after its host plant.

\section{Description}

Female: Body ventrally curved when relaxed, tapering at both ends but become swollen in pre-vulval region. Lateral field with three lines. Lip continuous with body contour, bluntly rounded, not setoff, almost hemispherical, with a slightly sloping side and a distinct depression at the oral apperture. Body cuticle marked by fine striae, nearly $1 \mu \mathrm{m}$ apart. Stylet slender with stout prominent knobs, which are backwardly directed. Excretory pore situated in the anterior region of basal bulb of the oesophagus. Oesophagus typical of the genus. Cardia small and rounded, about $4.2 \pm 0.3$ (3.4-5) $\mu \mathrm{m}$ long.

Reproductive system mono-prodelphic, ovary outstretched with a single row. Spermatheca almost spherical and filled with small spermatozoa. Vulva, a transverse slit with
Table 2. Measurements of the females of Paratylenchus thysanolus sp. nov. All measurements in $\mu \mathrm{m}$, except $\mathrm{L}$ in $\mathrm{mm}$.

\begin{tabular}{|c|c|c|c|}
\hline Characters & Holotype & Paratype & Juvenile \\
\hline $\mathrm{n}$ & & 11 & 3 \\
\hline Length & 0.29 & $0.16-0.29(0.22 \pm 0.0)$ & $0.16-0.19$ \\
\hline a & 19.4 & $13.5-20(17.8 \pm 1.8)$ & $14-16.6$ \\
\hline b & 4.0 & $2.5-4.4(3.3 \pm 0.5)$ & 2.9-3.3 \\
\hline c & 17.4 & $8.6-20.6(14.2 \pm 3.3)$ & - \\
\hline DGO & 6.8 & $5.1-6.8(5.9 \pm 0.8)(n=4)$ & - \\
\hline V & 81 & $79-83(80.1 \pm 2.2)$ & - \\
\hline VL/VB & 4.1 & $3.1-4.6(3.8 \pm 0.4)$ & - \\
\hline St $\% \mathrm{~L}$ & 6.3 & $6.3-11.3(7.7 \pm 1.4)$ & $9-9.8$ \\
\hline Oeso.\% L & 38 & $33-40.5(36.6 \pm 2.6)$ & $32-35.3$ \\
\hline Lip width & 5.1 & $5.1-6.8(5.7 \pm 0.8)$ & 5.1 \\
\hline Lip height & 3.4 & 3.4 & 3.4 \\
\hline Stylet length & 18.7 & $17-18.7(17.4 \pm 1)$ & $15.3-17$ \\
\hline Stylet knob width & 5.1 & $3.4-6.8(5.3 \pm 1.1)$ & 3.4 \\
\hline Stylet knob height & 3.4 & $1.7-8.5(4.2 \pm 1.9)$ & 3.4 \\
\hline Metenchium length & 11.9 & $8.5-11.9(10.0 \pm 1.5)$ & $6.5-8.5$ \\
\hline Telenchium length & 6.8 & $6.8-8.5(9.7 \pm 1.4)$ & 8.5 \\
\hline Oesophagus length & 76.5 & $64.6-78.2(71 \pm 4.3)$ & $54.4-61.2$ \\
\hline Procorpus & 30.6 & $23.8-30.6(26.5 \pm 1.9)$ & $20-25.5$ \\
\hline Metacorpus & 17 & $15.3-19.5(16.6 \pm 1.2)$ & $15.3-20$ \\
\hline Isthmus & 13.6 & $11.9-15.3(12.1 \pm 3.6)$ & $8.5-10.2$ \\
\hline Basal bulb & 11.9 & $10-13.6(11.7 \pm 1.3)$ & $8.5-11.9$ \\
\hline Excretory pore & 61.2 & $42.5-61.2(55.7 \pm 6.9)$ & $44.2-45.9$ \\
\hline Body width & 15.3 & $10.2-13.6(12.5 \pm 1.5)$ & $10.2-11.9$ \\
\hline G1 & 38 & $33-40.5(36.6 \pm 2.6)$ & - \\
\hline Vulval length & 56.1 & $37.4-56(44.9 \pm 4.9)$ & - \\
\hline Vulval width & 13.4 & $10.2-13.6(12.0 \pm 1.3)$ & - \\
\hline Tail & 17 & $13.6-20.4(16.6 \pm 2.4)$ & $17-18.5$ \\
\hline Anal body diameter & 8.5 & $6.8-8.5(7.7 \pm 0.8)$ & 8.5 \\
\hline
\end{tabular}

prominently rounded lateral vulvar membrane. Tail tip curved gently ventrad, conoid, narrows gradually to a bluntly rounded terminus.

Male: Body gently ventrally arcuate after fixation. Body narrows at anterior end to a rounded head at terminus and posterior from the region of the cloaca to an acute terminus. Head sloping with fine annule and sclerotization very light. Stylet lacking. Oesophagus degenerated.

Excretory pore distinct, near the nerve ring. Lateral field with three lines. Body annules very fine. Testis full of large refractive spermatozoa. Anal sheath prominent and short. Spicule curved slightly. Tail straight, narrows to give a very slender conoid outline with an acute terminus. 


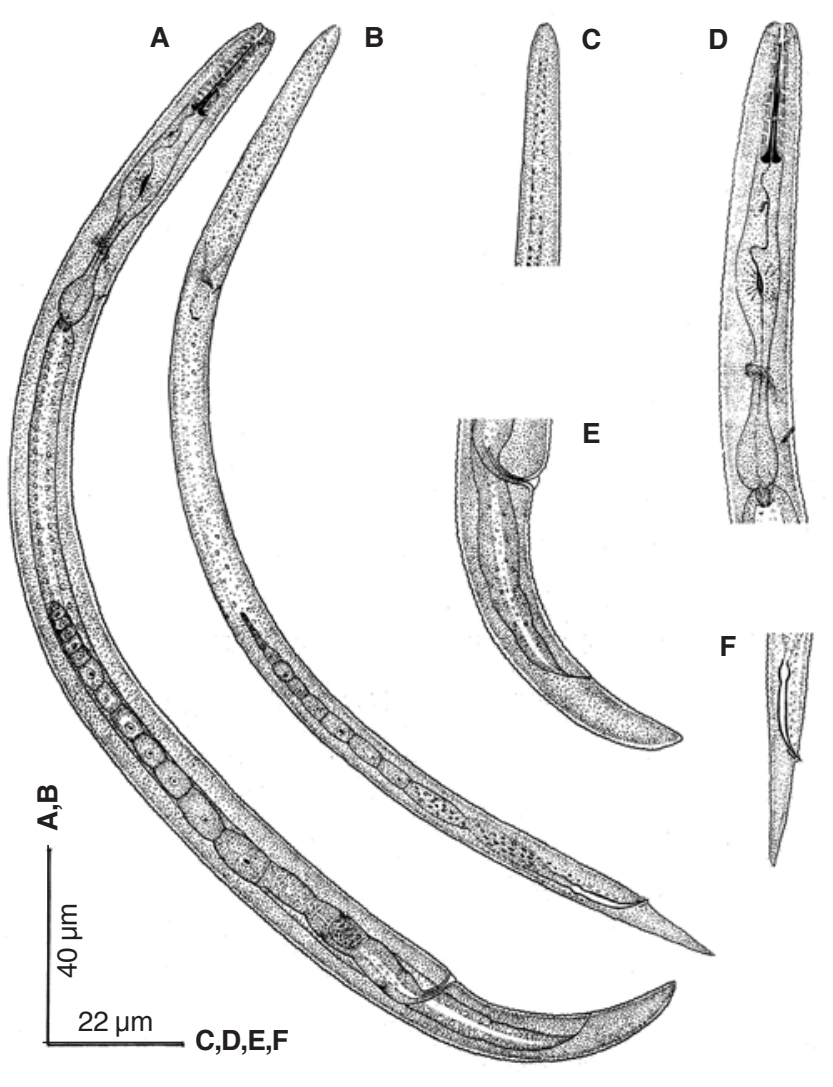

Figure 1. Paratylenchus thysanolus sp. nov.

A - Female, entire body; B - Male, entire body; C - Male, anterior body; D - Female, anterior body; E - Female, tail region; F - Male, tail region.

\section{Type habitat and locality}

Soil around the rhizosphere of Thysanolaena maxima (Roxb.) Kuntz. from Waithou hill, Thoubal district, Manipur.

\section{Diagnosis and relationships}

Paratylenchus thysanolus sp. nov. is distinct in having smaller body, bluntly rounded lip with a distinct depression at the oral aperture and heterogeneous tail shape in between male and female. The new species comes close to $P$. variatus Jairajpuri, 1982 and P. colbrani Raski, 1975. From P. variatus, it differs in the body length, stylet length, oesophagus length and shape
Table 3. Measurements of the male of Paratylenchus thysanolus sp. nov. All measurements in $\mu \mathrm{m}$, except $\mathrm{L}$ in $\mathrm{mm}$.

\begin{tabular}{ll}
\hline Characters & Paratype \\
\hline $\mathrm{n}$ & 3 \\
Length & $0.23-0.24(0.24 \pm 0.0)$ \\
$\mathrm{a}$ & $24-28(26.6 \pm 1.8)$ \\
$\mathrm{b}$ & $12.8-14.4(13.4 \pm 0.7)$ \\
$\mathrm{C}^{\prime}$ & $1.6-2.2(2 \pm 0.3)$ \\
$\mathrm{T}$ & $26.9-34.5(29.4 \pm 3.5)$ \\
Spicule & $16-17(16.6 \pm 0.4)$ \\
Gubernaculum & 5.1 \\
Excretory pore & $54.4(\mathrm{n}=1)$ \\
Body width & $8.5-10.2(9.0 \pm 0.8)$ \\
Tail & $17.0-18.7(18.1 \pm 0.8)$ \\
Anal body diameter & $6.8-8.5(7.9 \pm 0.8)$ \\
\hline
\end{tabular}

of tail $(\mathrm{L}=0.21-0.31 \mathrm{~mm}, \mathrm{~b}=3.6-4.3$, stylet $=15-16 \mu \mathrm{m}$, oesophagus $=55-65 \mu \mathrm{m}$, tail conoid with variable shape, often digitate or indented in $P$. variatus). It is distinguished from $P$. colbrani in its smaller body length, value of 'a', 'b', lesser excretory pore length, prorhabdion and lateral fields $(\mathrm{L}=0.28$ $0.33 \mathrm{~mm}, \mathrm{a}=19-26, \mathrm{~b}=3.7-5.4$, prorhabdion $=8-10 \mu \mathrm{m}$, excretory pore $=63-79 \mu \mathrm{m}$, lateral fields $=4$ lines in $P$. colbrani) . The present specimen also differs from $P$. canchicus, $P$. longicaudatus and $P$. lepidus in its smaller body length, lesser value of 'a', smaller length of stylet and oesophagus, much smaller tail length.

\section{References}

Jairajpuri, M.S. (1982). Three new species of nematodes from sugarcane. Revue Nematol. 5(2): 2 14-246.

Micoletzky, H. (1922). Die freilebenden Erd-Nematoden. Arch. Naturg. Berlin Abt.

Mohilal, N. \& Ch. Dhanachand (2004). Two new species of Paratylenchidae from Manipur. Uttar Pradesh Journal of Zoology 24(2): 173-177.

Raski, D.J. (1975). Revision of the Genus Paratylenchus Micoletzky, 1922 and descriptions of new species - part I. Journal of Nematology 7(1): 15 - 34 .

Seinhorst, J.W. (1959). A rapid method for the transfer of nematodes from fixative to anhydrous glycerin. Nematologica 4: 67-69.

Seinhorst, J.W. (1962). On the killing, fixation and transferring to glycerine of nematodes. Nematologica 8: 29-32. 